\title{
Electrocatalytic Reduction of Nitric Oxide by Cytochrome P450-modified Gold Electrodes
}

\author{
Guang Shan Xuan, Seunho Jung,", and Sunghyun Kim" \\ Department of Chemistry and Bio/Molecular Informatics Center, Konkuk Universin: Seoul 1+3-701, Korea \\ "Department of Microbial Engineering and Bio/Molecular Informatics Center, Konkuk liniversity, Seoul 143-701, Korea \\ Recened Octoher 29, 2003
}

Key Words : Cytochrome P450, NO reduction, Modified electrodes, Impedance

Detection of NO has drawn much attention as NO plays important roles in physiological processes such as neurotransmission, muscle relaxation and immune system mediation. ${ }^{1-i .}$ Extensive work has been made to develop efficient electrochemical systems for the NO detection. Among them are metallo-porphyrins (MPs), ${ }^{4}$ phthalocyanines (MPcs) ${ }^{5}$ and metalloproteins such as hemoglobin ${ }^{6}$ and myoglobin. ${ }^{7}$ NO easily undergoes oxidation or reduction through the axial ligation to the active site.

Among heme-containing proteins, P450 class is of particular interest in that they are ubiquitous enzymes that are found both in prokaryotes and eukaryotes, catalyzing monooxygenation reactions for a great variety of organic compounds. ${ }^{89}$ There have been efforts of utilizing P450s for the synthetic purpose in a regio- and stereo-specific manner. The natural use of $\mathrm{P} 450$ requires cofactors such as $\mathrm{NAD}(\mathrm{P}) \mathrm{H}$ and electron-transfer proteins such as $\mathrm{P} 450$-reductase, which is one of main obstacles to the commercial implementation. Estabrook ${ }^{10}$ and Vilker ${ }^{11}$ reported that it was possible to maintain catalytic activities of $\mathrm{P} 450$ for the substrate conversion when a cofactor was replaced by the electrode as an electron donor to $\mathrm{P} 450$ dissolved in solution. A redox mediator between the electrode and P450 may or may not be required depending on systems. As a nitric oxide reductase, cytochrome $\mathrm{P} 450$ accepts electrons from $\mathrm{NAD}(\mathrm{P}) \mathrm{H}$. There are a number of works on the active site structure and NO reduction mechanism. ${ }^{12-15}$ IJere we report the usc of cylochrome P450 adsorbed on the electrode surface as an electrocatalyst for the detection of NO through the direct electron transfer reaction.

Cylochrome P450 2B4 (CYP2B4) was purchased from Sigma and used as received. The $\mathrm{P} 450$ solution was made by dissolving $3 \mathrm{mg}$ of CYP2B4 in $1 \mathrm{~mL}$ of tris buller ( $10 \mathrm{mM})$ containing $10 \%$ glyccrol. $10 \mu \mathrm{L}$ was applied to the precleaned gold surface (denoted as Au/P450) for I $h$ and the electrode was washed with water before use. MPA (3mercaptopropionic acid) treatinent was done on the $\mathrm{Au} / \mathrm{P} 450$ electrode. When treated with MPA, $5 \mu \mathrm{L}$ of $10^{-3} \mathrm{M}$ MPA solution was added to the Au/P450 electrode (denoted as Au/P450-MPA) and $30 \mathrm{~min}$ was allowed. Figure 1 shows the cyclic voltammograms of $\mathrm{Au} / \mathrm{P} 450$ (curve a) and $\mathrm{Au} / \mathrm{P} 450$ MPA (curve b) in $\mathrm{pH} 7.0$ tris buffer solution. Without MPA.

"Co-Conesponding Authors: Sunghyun Kim (skim 100@konkuk. ac.kr); Scunho Jung (shjung (ôkonkuk.ac.kr)

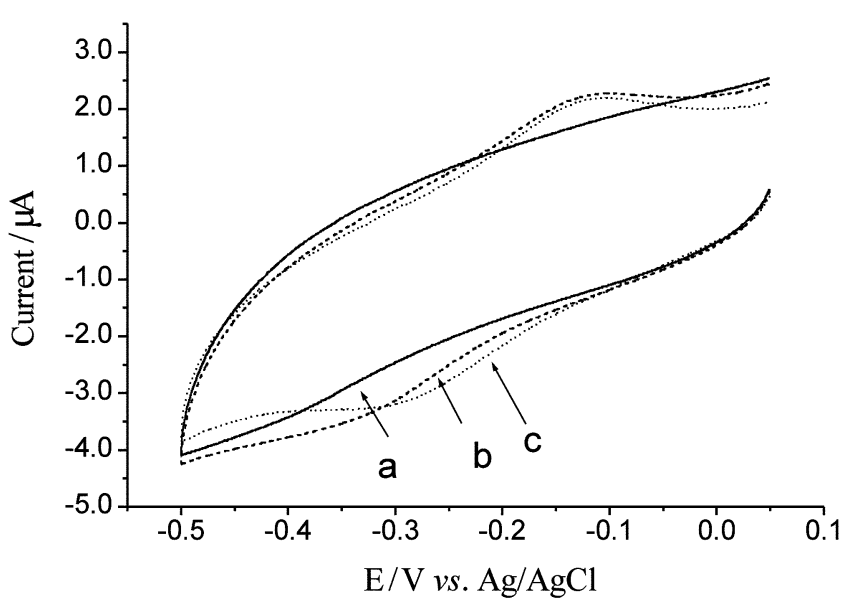

Figure 1. Cyclic voltammograms of adsorbed cylochrome $P 450$ $2 \mid 34$ wilhout (curve at solid line) and with (curve b. disshed line) MPA. Curve e (dotted line) was obtained at a $\mathrm{Au} / \mathrm{P} 450-\mathrm{MPA}$ slectrode after injecting $\mathrm{NO}$. Scan rate $=0.05 \mathrm{~V} \mathrm{~s}$ '; clectrode area $0.071 \mathrm{~cm}^{2}$.

the voltammetry does not show any distinct redox peaks corresponding to the heme group. This is contrary to our expectation since unlike to other heme-containing proteins. the heme group in $\mathrm{P} 450$ is highly exposed so that the direct electron transfer can be possible, otherwise some molecular wirings may be needed. However, upon treatment with MPA, a distinct pair of redox peak was observed.

This is probably due to the fact that negatively charged MPA $\left(\mathrm{pK}_{\mathrm{il}}-6.0\right)$ provides a desirable environment for CYP2B4 (pl-8.5) to undergo facile electron transfer reactions through electrostatic interaction between MPA and CYP2B4. This interaction can induce close packing of CYP2B4 on the surface and thus a favorable orientation toward electron transfer. The coverage from a voltammetric area was calculated to be $c a .9 .0 \times 10^{-11} \mathrm{~mol} \mathrm{~cm}^{-2}$, indicating a multilayer system, determined from the molecular size of $10 \mathrm{~nm}$. The peak current was linearly proportional to the scan rate, showing that the enzyme was adsorbed on the surface. The peak separation slightly increased with scan rate having a formal potential $\left(E^{\left(t^{\prime}\right.}-\left(E_{p . \mathrm{a}}+E_{\mathrm{p} . \mathrm{c}}\right) / 2\right)$ at $c a \cdot-0.22$ $V$. suggesting a quasi-reversible electron transfer kinetics.

Impedance spectroscopic measurements with $2.5 \mathrm{mM}$ $\mathrm{Fe}(\mathrm{CN}){ }_{6}{ }^{3-} / \mathrm{Fe}(\mathrm{CN})_{6}{ }^{4-}(\mathrm{I}: \mathrm{l})$, based on the Randles equivalent circuit ${ }^{17}$ which describes the heterogeneous electron transfer reactions, also support that the observed electrochemical 


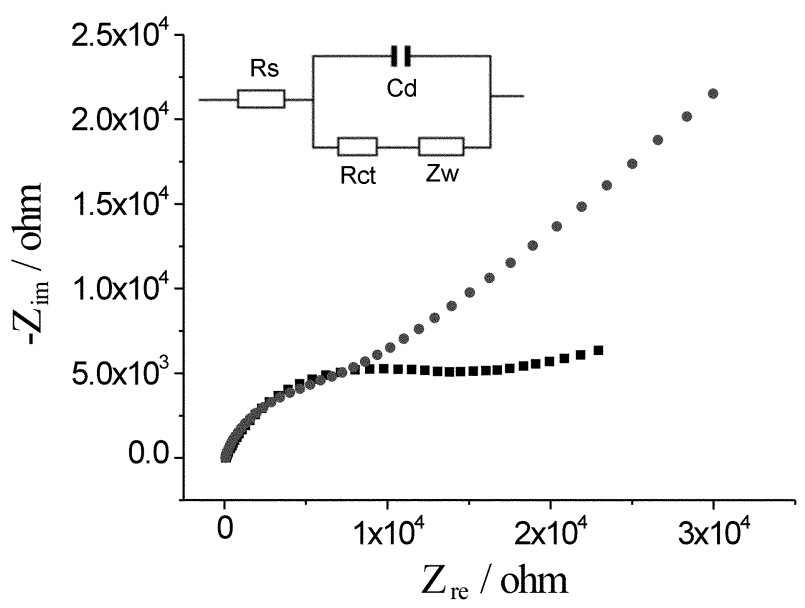

Figure 2. Nicpuist plot of $\mathrm{Au} / \mathrm{P} 450(\boldsymbol{a})$ and $\mathrm{Au} / \mathrm{P} 450-\mathrm{MPA}(\bullet)$ systems in the presence of $2.5 \mathrm{mV} \mathrm{le(C)})_{6}^{3-} \mathrm{Fe}(\mathrm{CN})_{6}{ }^{-}(\mathrm{I}: \mathrm{I})$ couple. Potential was held at $0.22 \mathrm{~V}$. Insct: Randles equivalent circuit to represent the system.

behavior comes from the MPA effect (Figure 2). The reduced charge transfer resistance of $8.6 \mathrm{k} \Omega$ for $\mathrm{Au} / \mathrm{P}^{4} 450 \mathrm{M}-\mathrm{MPA}$ from $14.8 \mathrm{k} \Omega$ for $\mathrm{Au} / \mathrm{P} 450$ and the observed diffusional process of $\mathrm{Fe}(\mathrm{CN})_{6}{ }^{3-} / \mathrm{Fe}(\mathrm{CN})_{6}{ }^{4-}$ in the presence of MPA clearly show that MPA reorients CYP2B4 molecules in a way that fast electron transfer is possible. A linear part observed in the Nyquist plot indicates that $\mathrm{Fe}(\mathrm{CN})_{6}{ }^{3-} / \mathrm{Fe}(\mathrm{CN})_{6}{ }^{4-}$ redox reaction is diffusion-controlled by exchanging electrons with CYP2B4.

Upon addition of NO, the reduction current was observed with a cathodic peak shifted by $c a .40 \mathrm{mV}$ toward positive potential (Figure lc). This suggests that NO binds to the ferric state of a heme group before reduction. The similar shift in the redox peaks of iron was observed when $\mathrm{CO}$ was added to the $\mathrm{P}^{\mathrm{P}} 450$-adsorbed electrodes. ${ }^{18.19}$ In that case, both cathodic and anodic peaks were shifted by more than $80 \mathrm{mV}$. However, neither $\mathrm{CO}$ reduction nor $\mathrm{CO}$ oxidation was observed, indicating $\mathrm{CO}$ simply binds to the iron site. A smaller potential shift in our case explains either NO does bind to Fe not as strongly as $\mathrm{CO}$, or only some part of $\mathrm{P} 450$ is exposed to NO. Notable is that the anodic peak position did not change even with NO. This strongly suggests that once $\mathrm{NO}$ is reduced. the reduction product(s) does not remain on the surface. A catalytic reduction mechanism of in the case of formation of $\mathrm{N}_{2} \mathrm{O}$ could be written as below.

(heme) $\mathrm{Fe}^{3+}+\mathrm{NO} \rightarrow$ (heme) $\mathrm{Fe}^{3+}-\mathrm{NO}$

(heme) $\mathrm{F} \cdot \mathrm{e}^{3+}-\mathrm{NO}-\mathrm{H}^{-}+2 \mathrm{e} \rightarrow$ (heme) $\left(\mathrm{Fe}^{2-}-\mathrm{NO}\right)-\mathrm{H}^{-}$ (heme) $\left(\mathrm{Fe}^{2-}-\mathrm{NO}\right)-\mathrm{H}^{-}+\mathrm{NO}+\mathrm{H}^{-} \rightarrow\left(\right.$ heme) $\mathrm{Fe}^{3+}+\mathrm{N}_{2} \mathrm{O}+\mathrm{H}_{2} \mathrm{O}$

The possibility of CYP2B4-modified electrode as a NO sensor was tested by amperometric measurements. A concentrated solution of nitrite was added to the iodidecontaining solution at $\mathrm{pH} 2.0$ while poising the potential at $-0.37 \mathrm{~V}$ where the NO reduction took place. NO was produced by the catalytic decomposition of $\mathrm{NO}_{2}{ }^{-20}$

$$
2 \mathrm{I}+2 \mathrm{NO}_{2}+4 \mathrm{H}^{+} \rightarrow \mathrm{I}_{2}+\mathrm{NO}-2 \mathrm{H}_{2} \mathrm{O}
$$

Figure 3 shows a linear response at least down to sub ppm

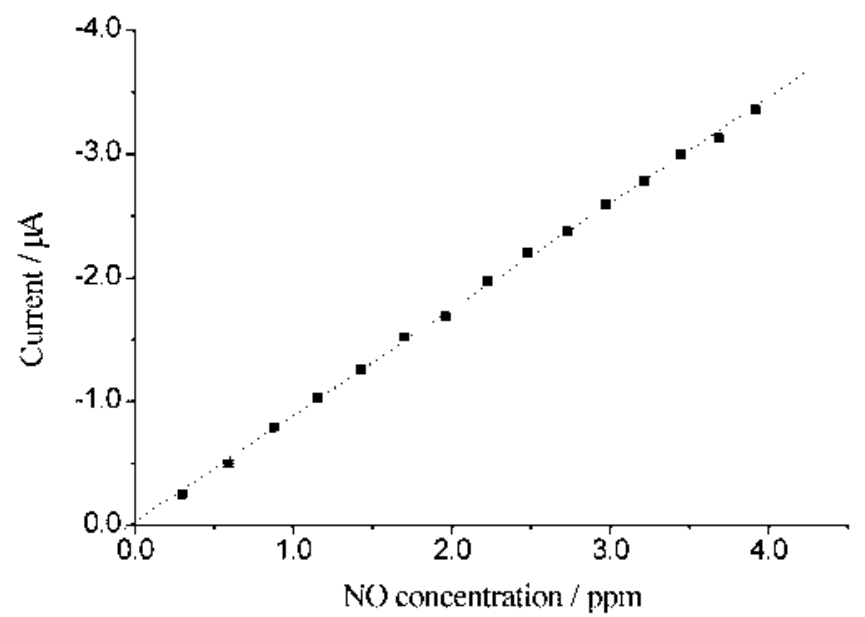

Figure 3. Plot of reduction current is $\mathrm{NO}$ concentration from amperometric experiments. $/$-factor of tit $=0.9995: \nu$-intercept $=-0.032$.

concentration with an $r$-factor of 0.9995 and $y$-intercept of $-0.0032 \mu \mathrm{A}$.

In conclusion, we demonstrated that cytochrome p450 could be electrochemically activated without a cofactor or a mediator. The direct electron transfer was possible between the electrode and CYP2B 4 with an aid of MPA. CYP2B4modified electrodes were used to detect dissolved NO.

Acknowledgment. This work was supported by Korea Research Foundation Grant (KRF-2002-070-C00066).

\section{References}

1. Burdett. A. L.: Lowenstein. C. J.: Bredt. D. S.: Chang. T. S. K.: Snyer. S. HI. Seience 1992. 257, 401.

2. Kovacic. P. Bioelect. Bioenerg. 1996, 39. 155.

3. Murad. I. Angew Chem. Int. Fd 1999. 38.1856

4. Yao. D.: Vlessidis. A. G.: Eviniridis. V. I' Anat (hm acta 2001. 435. 273 .

5. Choi. H. J.: Kwag. G.: Kim. S. J. Electrownal Chem 2001. 508. 105.

6. Ian. C.: L. (i.: \%hu I.: Thu. D. Anat Chin tata 2000 . +23.95.

7. Bayachou. M.: Lin. R.: (ho. W. larmer. P. J. Am. (hem. Soc. 1998. $22 \% .9888$.

8. Guengerich. F. P. J. Biol. Chem. 1991. 266.10019.

9. de Visser. S. P.: Shaik. S. J. Am. Chem. Soc 2003. 125. 7413.

10. Ftabrook, R. W. Faulkner. K. . .: Shet, M. S. Fisher. C.W. Methods Enzmol. 1995. 272. 44.

11. Rejpa. V.: Mayluew. M. P.: Vilker. V. L. Proc Nat, Acad Sor. LS. 1997. 94. 13554.

12. Radu. S.-D. Eirf J. Inoug Chen 2003. 6. 1048.

13. Daibcr. A.: Vauser. T.: Takaya. N.: Kudo. T.: Webcr. P.: Hultschig. C.: Shoun, II.: [1]rich, V. J. Inorg. Chem 2002, 88, 343.

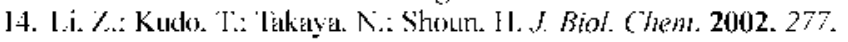
33842 .

15. Harris. D. Int. I. Onten. ('hem. 2002. 88.183

16. Hong. H.: Park. W.: Yu. E. Bull. Korean Chem. Soc. 2000. 21. 23.

17. Randles. J. E. B. Disc: Farday Soc. 1947. /.11.

18. I ci. C.. Wollenberger, U.: Jung. C.: Scheller. $\Gamma$. W. Biochem. Biophys. Res. Commun. 2000. 268.740.

19. Zhang. Z.: Niassar. A. J.. L.u. K.: Schenkman. J. B.: Rusling. J. E.J. (hem. Soc Fonden Trans. 1997. 93. 1769.

20. Fan. C.: Pang. J.: Shen. P.: Li. G.: Zhu. D. Afut Sci. 2002. /s. 129 . 